\title{
TOURISTIC SIGNIFICANCE OF „THE SARAJEVO FILM FESTIVAL“ IN BOSNIA AND HERZEGOVINA
}

\author{
Rahman Nurković ${ }^{1}$
}

\begin{abstract}
The aim of this paper is to show the touristic significance of the Sarajevo Film Festival on development of film and accompanying industry, which would be, at the same time, the best support to promotion of Sarajevo, and the whole country, as one of the most interesting tourist and cultural destinations of South East Europe. Event tourism is among significant branches of the economy that have been recently developing dynamically in Bosnia and Herzegovina. Tourists no longer travel around Bosnia and Herzegovina in order to take photos of some contents. They travel in order to gain a new experience, to be part of some cultural, religious, educational or similar contents. In this context, Sarajevo with the Sarajevo Film Festival has a lot to offer. Touristic significance of the Sarajevo Film Festival on development of local community and tourism is extremely high.
\end{abstract}

Key words: the Sarajevo Film Festival, Bosnia and Herzegovina, tourism.

\section{INTRODUCTION}

Cultural events have always played an important role in society: to mark significant moments for community; to mark, in cyclically understood time, the beginnings and endings of production cycles; as religious celebrations, patron saint festivities, as cultural festivals and fairs. In the contemporary world, events experience a significant transformation again by getting primarily an instrumental role of means of economic development and their positioning in regional, national and global frames. It can therefore be said that today their role becomes central to developmental strategies of cities and regions (see: Richards \& Palmer, 2013; Goldblatt, 2008; Getz, 2007; Landry, 2000; Krasojević, 2013).

Keeping such picture in mind, Greg Richards in publication „Events and Means of Drawing Attention" (Richards, 2013) points to a change of importance of the means of production and the means of consumption in the contemporary world. According to Richards (2013), the key role that events play in the contemporary society reflects on their ability to attract attention of consumers. The Sarajevo Film Festival is often classified in the field of tourism. Festivals, therefore, function as something accidental, something that simply 'happened' in Sarajevo. This article will show, on the contrary, that even that 'accidental tourism' appeared due to not quite accidental social and spatial factors. The Sarajevo Film Festival is therefore understood as a cultural form, whose meanings and instrumentalizations were created in dialectics, with the broader socio-political situation and needs in Bosnia and Herzegovina.

\footnotetext{
${ }^{1}$ Full Professor, Department of Geography, Faculty of Science, University of Sarajevo, Zmaja od Bosne 33-35, 71000 Sarajevo, Bosnia and Herzegovina
} 


\section{WORK METHODS AND DATA SOURCES}

In empirical part of this article, testing of the set hypotheses is being performed by using quantitative methods in economy. As already mentioned, basic objectives are to determine the satisfaction level of event attendees, to determine structure of guests attending the event, and to investigate whether the satisfaction is associated with repeated return of visitors to the Sarajevo Film Festival and a possibility of recommendation to other persons. Methods of descriptive statistics, graphic and tabular reviews, correlation analysis, as well as non-parametrical, the Mann-Whitney U test and the Kruskal-Wallis test have been used. With using the methods of descriptive statistics computation of characteristic values such as the arithmetic mean, the standard deviation as a measure of dispersion the values around arithmetic mean, mode, median, and minimum and maximum value is being performed. Graphic and tabular reviews show the participation of different research modalities, while the association between the directions of two variables is tested with correlation analysis. As it is about a level of agreement that is expressed in a Likert scale, it can be said that the values have the characteristics of ordinal scale, and because of that, it is appropriate to test the association with Spearman's rank correlation coefficient. In testing the difference between the attitudes that were measured by Likert scale (level of agreement) with regard to categorical variable (variable expressed in words, for example, gender, level of education and similar) non-parametrical Mann-Whitney U test was used in case that a categorical variable had two modalities, while in case that a categorical variable had more than two modalities for testing the difference in levels of agreement using the Kruska-Wallis test was suitable. For the purpose of testing the set hypotheses, the data on attitudes of respondents about the Sarajevo Film Festival were gathered. The data were provided through a questionnaire as a research instrument.

\section{DIFFERENTIATION OF DEVELOPMENT OF CULTURAL EVENTS IN SARAJEVO}

The beginnings of development of the Sarajevo Film Festival go back in the time of four-year siege of Sarajevo. In mid-1995, Obala Art Centar initiated the festival in order to make its contribution to creating a better future-reconstruction of civil society and holding cultural events in the capital of Bosnia and Herzegovina. (Richards \& Palmer 2013). The last, 22nd Sarajevo Film Festival, was held in Sarajevo, and is held in the capital every year, which makes it particularly important for development of cultural tourism in Bosnia and Herzegovina. Each film achievement has its audience from different parts of the world. While public persons and international celebrities usually walk the Bosnian red carpet in front of the National Theatre followed by applauses of the fans gathered around, Open Air Cinema offers the tourists watching films under the stars on the biggest screen in the region. (www.sarajevo-tourism.com) It makes a big 
and rich cultural offer of the Sarajevo Film Festival, which will be organised every year in the capital of Bosnia and Herzegovina for local and international tourists coming to Sarajevo. Although it was hard to believe, on the $27^{\text {th }}$ October in 1995, in the besieged city, the first festival during which, according to available research results, 37 films from 15 countries were presented in the Bosnian Cultural Centre, started developing Around 15.000 viewers showed their interest in the festival, whose projections were completely sold out. All that was happening was close to statement of an American actor, Gregory Peck, who said that tough times do not last, but tough people do. The Sarajevo Film Festival proved its serious intentions in all the following years, rising in quality, meaningfulness, production, always and once again to higher levels. This is how today's international film festival with a special significance for the South East region was created enabling that films, talents and future projects from the region get to the centre of attention of international film public. (Getz 1997). New films from all over the world are presented on the Sarajevo Film Festival, while the focal point of programme, which is accredited by FIAPE-International Federation of Film Producers Associations, offers an insight into the latest film production of the region, at a certain point. The Sarajevo Film Festival serves as a common platform for film business and tourism development of the whole region. This is the place where both producers and authors of this part of Europe encounter, and is known among film professionals all over the world as an extraordinary important place for exchange of ideas and information for all the people who want to know more on Bosnia and Herzegovina. (Krasojević 2013). The impact of the Sarajevo Film Festival on development of local community and tourism is exceptionally important. In that period a large number of tourists visit Sarajevo, the unique atmosphere is created in the streets and big opportunities for private business are also opened, while in these days a positive image of Sarajevo is spread by numerous world's media. Event tourism is one of branches of the economy in Bosnia and Herzegovina that has been developing intensely on global level lately. In world's context, cultural production is a basic motivator of contemporary urban economy; cultural events take one of the key places in processes of urban development, and cultural reception marks the image of places and cities. (Bianchini 1999). In Bosnia and Herzegovina, it is possible to expect similar effects, although the cultural events organised differently might make a more significant contribution to wider cultural, economic and social objectives, than it is at the moment. Keeping this in mind, the project strived to achieve the following results:

1. to identify those cultural events in Sarajevo having a tourist potential;

2. to make a classification of the existing cultural events in Sarajevo (on the grounds of a series of criteria relevant for their tourist potential);

3. to do mapping of cultural practices of the Sarajevo citizens, respectively of the demand for cultural events;

4. to offer a set of proposals for improvement of cultural offer in the event tourism domain in Sarajevo (improved quality, rising the capacities, spatial and temporal distributions of events, creating new and rationalization of existing cultural events, etc.) 


\section{RESEARCH RESULTS OF THE SARAJEVO FILM FESTIVAL}

Criterion for sample selection was that examinees visited the Sarajevo Film Festival in 2016. Survey results from of 350 examinees show that $70 \%$ of total number of visitors of the festival responded. The objective was forming the sample for survey that would consist of equal number of domestic and foreign guests at the Sarajevo Film Festival. According to estimation of visits of tourists, 3,83\% of total 4, it can be confirmed that they are satisfied with cultural value of Sarajevo city. Results of intersection of these criteria are shown in (Tables 1 and 2).

Table 1. Aesthetic value of the Sarajevo Film Festival 2016

\begin{tabular}{|l|r|r|}
\hline Aesthetic value & Frequency & Total mark f(x) \\
\hline I am very satisfied (4) & 201 & 804 \\
\hline I am satisfied (3) & 34 & 102 \\
\hline I am not completely satisfied (2) & 13 & 26 \\
\hline I am unsatisfied (1) & 0 & 0 \\
\hline TOTAL & 248 & 932 \\
\hline Average mark (f(x)/f) & - & 3,76 \\
\hline
\end{tabular}

Source: author's processing

Table 2. Cultural value of the Sarajevo Film Festival according to survey of tourists in 2016

\begin{tabular}{|l|r|r|}
\hline Aesthetic value & Frequency & Total mark f(x) \\
\hline I am very satisfied (4) & 205 & 820 \\
\hline I am satisfied (3) & 42 & 126 \\
\hline I am not completely satisfied (2) & 1 & 2 \\
\hline I am unsatisfied (1) & 0 & 0 \\
\hline TOTAL & 248 & 348 \\
\hline Average mark (f(x)/f) & - & 32 \\
\hline
\end{tabular}

Source: author's processing

With regard to specific orientation of this research, of almost 350 cultural events being held in Bosnia and Herzegovina, 195 events that are already tourist events or have a potential to become one, were mapped. The research was focused on the sphere of tourist valorisation, with the aim to provide events with sustainability and improvement in organisational and content regard. These data show a clear trend that in Sarajevo, with increase of the scope of events, cultural events in aesthetic sense occupy more and more significant place and among these the biggest number make the ones that are already touristically interesting (Fig. 1). This also indicates to the fact that, although development of tourist potentials of all the cultural events can make a significant contribution to their sustainability and improvement, the urgent task is development of 
tourist potentials of little cultural events being held in Bosnia and Herzegovina, their shaping into tourism products particularly those included in cultural events in anthropologic sense. (Richards \& Raymond 2000).

Several civilisation circles came into contact and mixed in the area of Bosnia and Herzegovina, in which three religions with enviable level of tolerance and approaching coexist, with no assimilation aspirations for integrations and creating a unique cultural pattern that would diminish the difference and uniqueness of the each cultural individuality. Its door opened so wide for the other and different, thus becoming a residence of domiciliary status and foreign parts, autonomy and heteronomy, of what is here and what is there, which is altogether an ideal toward which Europe itself has oriented. (Mercer 1991).

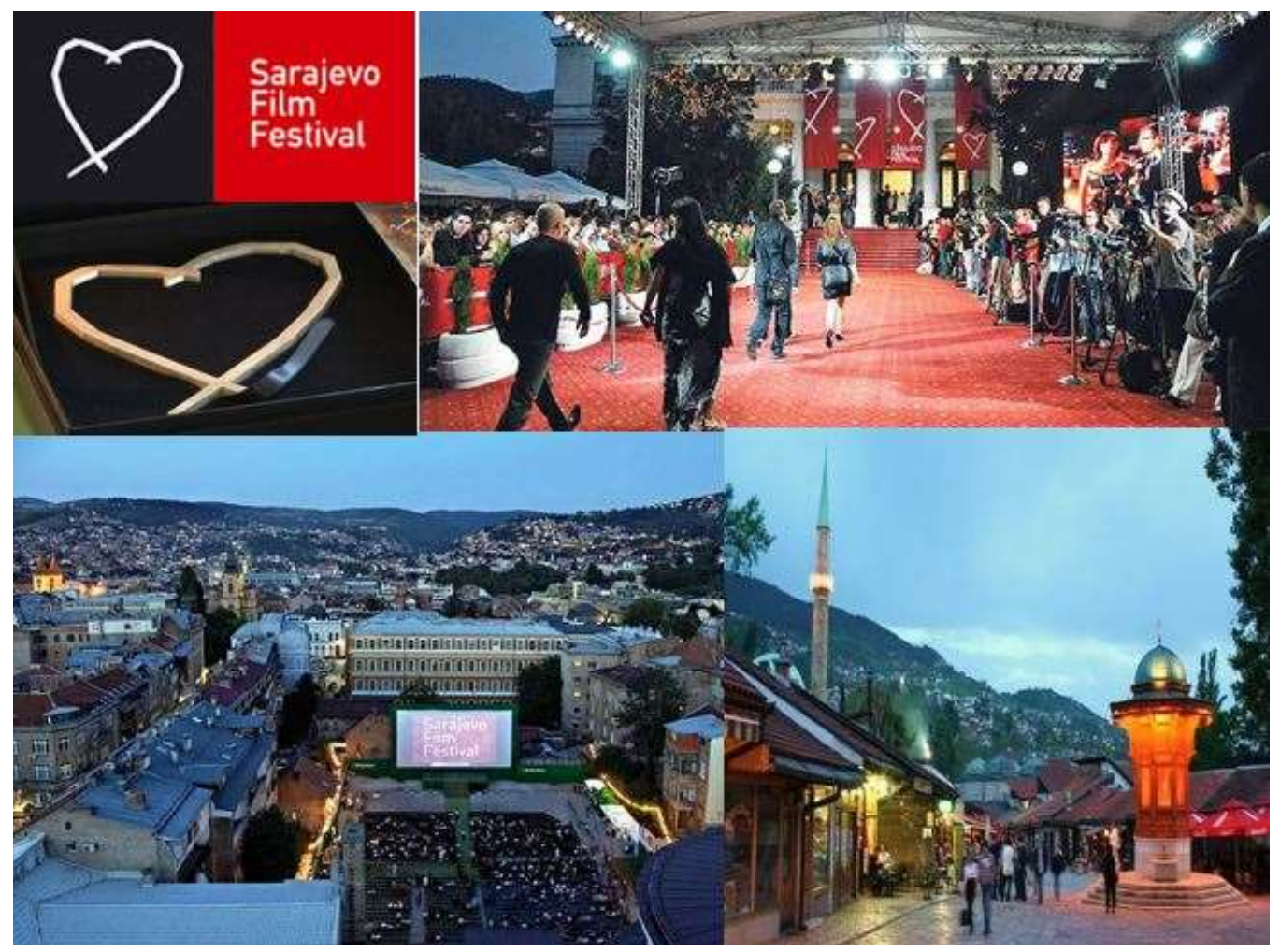

Fig. 1. The Sarajevo Film Festival in 2016

Source: Archives of Sarajevo Film Festival, 2016

Except for three constitutive people-Croats, Serbs and Bosniaks, representatives of the other national minorities also live in Bosnia and Herzegovina, who represent, through their actions, the most significant proof of recognising the different cultures in the time of globalisation, which is of the immeasurable value for development of intercultural dialogue and strengthening the social cohesion of the society. (Landry 2000). This is why a particular attention in determining the strategy of cultural policy of Bosnia and Herzegovina should be also paid to acting of national cultural and educational 
associations. The strategy of cultural policy in Bosnia and Herzegovina must keep this characteristic in mind and build it into foundations as an integrative factor of its existence. Perseverance of this idiom is at the same time both an appeal and an invitation for keeping and reaffirmation of the special and historically affirmed multiculturalism that gained unique and new dimensions in the experience of Bosnia and Herzegovina.

In spite of that, one should keep in mind the fact that the idea of multiculturalism itself, which is basically the cultural identity in Bosnia and Herzegovina, shouldn't be taken unambiguously; it does not always "cover" the same semantic content. In dependence of historical and geographic context, as well as of the level of democratization of social relations, it is always relatively different and is not expressed everywhere in the same manner; it's semantic and work content is contextual as well. In ethnocentric state communities, for example, the content of the idea of multiculturalism is reduced to a minority issue, in solving of which the face of democracy is reflected. Historic, and geographic context as well, show that multiculturalism in Bosnia and Herzegovina had its cultural forms that, among the other things, had also their common institutions, which have not, by fostering the cultural difference, generated separation, isolation, selforientation, but openness, communication and communal spirit; they have supported integrative, not disintegrative processes.

\section{PERSPECTIVES OF TOURISM IN BOSNIA AND HERZEGOVINA}

Many have realised the role and significance of tourism on regional development in Bosnia and Herzegovina, starting from the employees, through the institutes and governments. In this regard, the adequate strategy for tourism development was determined, which anticipated an enhanced development of tourist capacities and the increased number of domestic and foreign tourists. (Nurković 2009).

The need for restructuring the existing aspects and development of new aspects of tourism is one of the preferential needs for tourism development in Bosnia and Herzegovina. Number of beds should increase with simultaneous improving the quality of accommodation in hotela, villas and boarding houses. Total investment into tourism development should reach about 1,5 billion EUR.

According to estimations of the World Tourist Organisation (UNWTO), activities of travelling and tourism of Bosnia and Herzegovina for the period from 2006 to 2016 are expected to have a real annual growth of 5,2\%. Tourism in Bosnia and Herzegovina depends on four groups of factors: global, European, regional environment and the environment made by the system in Bosnia and Herzegovina and the Federation of Bosnia and Herzegovina, as well as market factors in the country and targeted markets, entrepreneural factors and their strength and motivation for acting in the tourism sector and the government. None of these factors can be isolated because all the mentioned factors can only jointly contribute to tourism development (Fig. 2) 


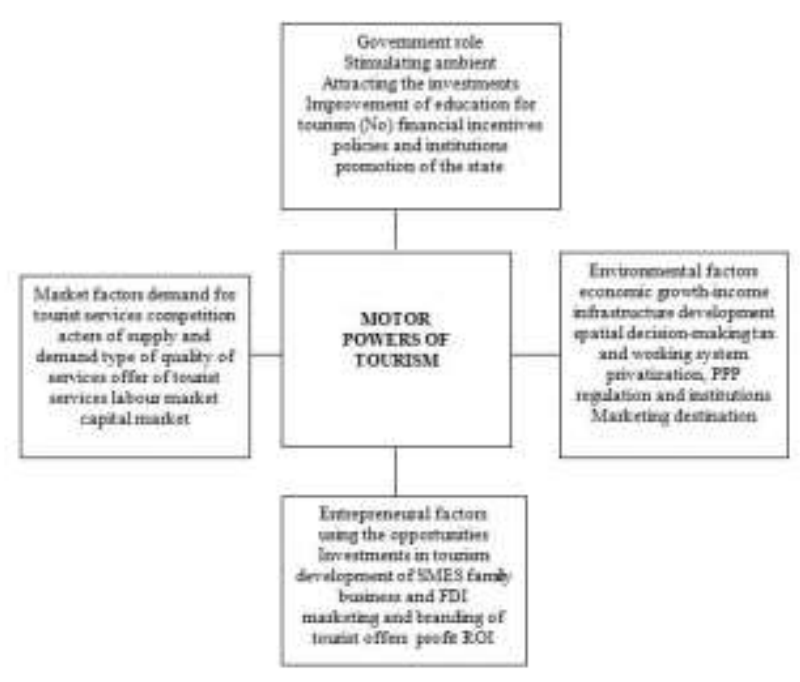

Fig. 2. Factors of tourism development in Bosnia and Herzegovina, 2016 Author: Nurković, R. 2016

Traffic is one of the key factors which influence the tourism development. Bosnia and Herzegovina has a significant position in transportation-communication system of the Balkans and south Europe. According to its position, it tries to join, as soon as possible, the developed European and world's countries, in domain of transport and communications, in which it has already achieved certain results. More recently, considerable funds have been invested into reconstruction of war-damaged and destroyed transport capacities, facilities and traffic lines, and the construction of new road and railway lines has been planned.

The existing traffic infrastructure in Bosnia and Herzegovina is located mainly around the central axis north-south along the Bosnia and the Neretva Rivers, and in the direction west-east, paralel to the Sava River. On these directions majority of economic and natural resources is located, including population of Bosnia and Herzegovina. Evident efforts have been made lately by Bosnia and Herzegovina and international community in order to normalize international transport gradually, but surely.

\section{CONCLUSION}

Tourism proved itself as one of the most important activities in Sarajevo. In that context, according to Plan of development of cultural tourism of the Sarajevo Canton, the aim of development of cultural tourism is to create the key mass of quality presented and professionally promoted cultural tourism products integrated into the complete tourist offer of destinations, that would create the images of destinations rich in cultural tourist offer, increase the satisfaction with visit of the existing guests, stimulate consumption, extend the season and stimulate the off-season demand, attract new market segments and initiate domestic demand. In the last few years we have 
witnessed a considerable increase in number of cultural festivals and events, which had a result that many cities all over the world are now organising one or more festivals dedicated to some form of arts. The Sarajevo Film Festival has also become part of this trend, for development of tourism.

This cultural event can be a significant factor of revival of local cultural life, creating a place image and promoting attractiveness of the place for tourism, thereby stimulating its economic development as well. Except for affecting the cultural offer improvement, the local communities make a tourist attraction of the place. The Sarajevo Film Festival also enables specific services within cinematographic industry, and with regard to certain circumstances, film directors can show their films and distributors have a possibility to watch and purchase them. The Sarajevo Film Festival is a specific and unique event that attracts the audience for different reasons. High quality products, i.e. the films that cannot be so easily found in cinemas, and with different themes, such as e.g. short films or documentaries, are offered. Furthermore, the Sarajevo Film Festival also offers other forms of activities such as courses, workshops and presentations. In this paper, satisfaction of the Sarajevo Film Festival visitors with the selected event elements, as well as their overall satisfaction with the event, has been tested.

Elements of the Sarajevo Film Festival that have been tested are certain aspects associated with the very programme of the festival, availability of 76 pieces of information, festival staff, location and the festival value for the visitors. For all five groups of the festival elements visitors declared themselves mainly satisfied (rating 4). The testing was also done to determine if there is a statistically significant connection between the Sarajevo Film Festival elements and the overall satisfaction, where the results have shown that there is a statistically significant, positive connection between the satisfaction with festival elements and overall satisfaction.

\section{REFERENCES}

1.Archives of Sarajevo Film Festival, 2016.

2.Bianchini, F. (1999). Cultural planning for urban sustainability. In L. Nystrom \& C. Fudge

(Eds.).(1999). Culture and Cities. Cultural Processes and Urban Sustainability (34-51). Stockholm: The Swedish Urban Development Council.

3.Getz, D. (1997). Event management and Event Touris. New York: Cognizant Communications Corporation.

4.Getz, D. (2007). Event Studies, Theory, Research and Policy for Planned Events. Amsterdam: Elsevier.

Goldblatt, J. (2008). Special Events, the Roots and Wings of Celebration. New Jersey: John Willey and Sons, Inc.

5.Krasojević, B. (2013). Strateško upravljanje kulturnim resursima u turizmu Srbije. Doktorska disertacija. Beograd: Univerzitet Singidunum. 
6.Landry, C. (2000). The Creative City: A Toolkit for Urban Planners. London: Earthscan.

7.Mercer, C. (1991). Brisbane's Cultural Development Strategy: The Process, the Politics, and the Products. In EIT The Cultural Planning Conference. Victoria, Australia: EIT

8.Mercer, C. (1991). What Is Cultural Planning? Paper presented to the Community Arts Network National Conference. Sydney, 10 October, 1991.

9.Nurković, R.. (2009). Influence of tourism on the Regional development of Bosnia and Herzegovina. International Journal of Euro-Mediterranean Studies 10.Richards, G. (2013). Events and the Means of Attention. Journal of Tourism Research \& Hospitality, 2 (2), 1-5. Richards, G., \& de Brito, M.P. (2013). The future of events as a social phenomenon. In: Richards, G., de Brito, M.P. \& Wilks, L. (eds) Exploring the Social Impact of Events. London: Routledge 11.Richards, G., Palmer, R. (2013). Uzbudljivi gradovi. Beograd: Clio 12.Richards, G., Raymond, C. (2000). Creative Tourism. ATLAS News, 23, 16-20. 